\title{
Pastoralism in Crisis: Mounting Challenges in Herding System in High Altitude Region of Nepal
}

\author{
Prabin Bhusal ${ }^{1}$, Mani Ram Banjade ${ }^{2}$ and Naya Sharma Paudel ${ }^{3}$
}

${ }^{1}$ Institute of Forestry, Pokhara Campus, Tribhuvan University, ${ }^{2}$ Future Himalaya Institute, Kathmandu, Nepal and ${ }^{3}$ ForestAction Nepal, Kathmandu, Nepal Corresponding author: bhusalp1@gmail.com

\begin{abstract}
This paper discusses on the mounting livelihoods challenges of high altitude region of Nepal driven largely by the growing conflict between pastoralists and community forestry (CF), and offers alternative pathways. The paper is based on a three-year action research using adaptive learning as an approach to understanding conflicts between the herders and CF members and other challenges around high altitude herding. The paper also brings the case of SuspaKshamawati Kalinchowk region with pragmatic issues and concerns that need urgent action. In addition, we analyse information on CF and other pastureland, institutional arrangements of CFUG, analysis of herders' livelihoods and review of policy process and relevant literature. The research shows that high altitude herding system has been facing several challenges with the conflict between the CF and herders as the main challenge. The conflict with CF has posed extreme threats to the existence of herding system in the region. Similarly, challenges like declining availability and access to quality pasture and hardship, and changing social values has contributed to decreasing herding number in recent years and has also put the unique transhumance livelihood activities in crisis. Finally, implications to policy and practice of CF and overall environmental governance are identified.
\end{abstract}

Key words: Community forestry, conflict, climate change, livelihood, Mountain pastoralism

\section{INTRODUCTION}

High altitude (High Himal and High Mountain) areas constitute 44.3 per cent of the total land area of Nepal out of which 23.9 per cent belong to the High Himal covering 25 districts (DFRS 2015). It encompasses the northern most part of Nepal towards the Tibet border with altitudinal range from $2000 \mathrm{~m}$ up to the alpine pasture (Acharya 2003). High altitude areas are inhabited by different ethnic groups like Sherpa, Rai, Limbus, Tamang, Jirel, Gurung, Thakali, and Magar and speak a variety of languages and dialects. The livelihood of the people here primarily depends on animal husbandry particularly Chauri (Yak), goats and sheep. High altitude herding is one of the predominant occupations practiced along these regions in Nepal. Yak/Nak/ Chauri herding is the key transhumance pastoralism ${ }^{1}$ practiced for generations in the Himalayan districts with total herd stock of 48,865 (GoN/MoLD 2017).

Pastoralism in the high mountains of Nepal merits more attention because of its significant geographical coverage, contribution to local livelihoods and national economy, and historically established cultural practices in animal husbandry (Ghimire and Parajuli 2001).

${ }^{1}$ Transhumance pastoralism is the seasonal movement of livestock between higher pasture in summer and lower temperate warmer region in winter to exploit the seasonal availability of forest and rangeland resources. In this case, we have more focused more on Yak/Nak/Chouri herding. 
The unique set of natural resources, inaccessible and tough geography and the natural resource base livelihood of people has been the key feature of these areas (Acharya and Baral 2017). The array of pasture in high altitude areas possesses about 80 per cent of Nepal's rangelands (Banjade and Paudel 2008; GoN 2014). The various forms of transhumance pastoralism have been the key livelihood strategy of the people in high mountains (Pandey and Chhetri 2005). Moreover, it has contributed to utilising the physically marginalised environmental resources for economically productive purpose (McVeigh 2004). The combination of crop production, animal husbandry and trade has been the foundation of economy in the Himalayan landscape (Bauer 1989; Bauer 2004).

During the last couple of decades, however, this important natural resource is depleting thereby undermining the productive capacity of the pasture land (Barsila 2008). There are ranges of biophysical and social factors including the introduction of community forestry (CF) which have contributed to the decline in high altitude herding (Joshi et al. 1994). Some of the important factors include i) gradual shrinking of productive grazing lands due to constraints posed by the CF on traditional routes, ii) dwindling interest of the new generation (Shrestha et al. 2006), iii) rapidly changing lifestyle (Brower 1990; Pandey and Chhetri 2005), iv) climate uncertainty including less rainfall/ snowfall, and v) changing vegetation growth (Barsila 2008; Parajuli et al. 2013). Similarly there is increasing deforestation and forest degradation mainly for firewood, construction of Goth (shed) and also for the trade that has brought the change in the highly sensitive ecotype of the region (Baral et al. 2012). Unfortunately, there have been little substantive studies around high altitude herding and late realisation of the concerned authorities on the value and importance of high altitude resource management. Consequently, high altitude landscape is almost invisible in the national policy debate, policy provisions and programmatic priorities. The blanket policy approach has almost ignored the socio-cultural, economic and ecological aspects of uniquely positioned intricate relations between the high hill forest ecosystems and the livelihoods of the people dependent on them (Banjade and Paudel 2008). On the other hand, the government imposition on livelihood of transhumance pastoralism in the name of protected area system has posed challenges over the sustainability of this unique ecological system. In this context, the paper aims to analyse range of issues that are playing significant role in the depletion of high altitude herding with particular focus on conflicts between the CF and herders.

The research has adopted a qualitative and interpretative method using interviews with the herders, focus group discussion with the key stakeholders, observation and transect walk of forestlands and herding sites. It is supplemented by review of relevant literature, analysis of community forest operational plans, assessment of biophysical status and environmental changes and researchers' experience on the issue. The central theme of the paper builds on the specific site level case of Suspa-Kshamawati community forest user group (CFUG) where we have employed adaptive learning and participatory action research. 
This paper is structured into five sections. Following the introduction, the second section discusses on the issues of high altitude pastoralism in Nepal. The Suspa-Kshamawati case, with its details on CFUG and herding landscapes, the natural resource and livelihood relations; story of a herder and the key issues around herding are discussed in the third section. It is followed by the discussion section and finally, the paper concludes with a few suggested areas, that require policy thinking or further research.

\section{HIGH ALTITUDE PASTORALISM IN NEPAL: KEY CHALLENGES}

While there are several natural and social factors shaping the high altitude landscape, we analyse three key challenges, namely declining quality and quantity of rangeland, changing social values, and weak or unclear tenure rights and resulting conflicts between the community forest and herders. These factors are discussed below.

\section{Declining Availability and Access to Pasture Land}

Pastureland ecosystems in Nepal are comprised of grasslands, pastures and shrub lands that cover about 12 per cent of country's land area. About 79 per cent of the pasturelands are located in the High Mountains and High Himal areas and 17 per cent in Middle Mountains (GoN/MoFSC 2014). Pastureland is an important source of forage, but due to poor management, only 37 per cent of the forage is accessible to livestock in Nepal (Ning et al. 2013). In addition, the quality of these pastureland has been decreasing rapidly due to various factors including lack of effort in pasture management, and over exploitation of accessible pasturelands. Neither the government nor other actors have laid efforts in increasing the productivity or regulating activities that have adverse effect on the quality of pastureland. Likewise, increasing extraction of timber and fuel wood and lopping and branch cutting for fodder has worsened the forest condition. Moreover, the forest has been poorly managed or undermanaged (Acharya and Baral 2017). Similarly, increasing infrastructure development, mainly the roads and tourism, has triggered deforestation and forest degradation.

On the other hand, poorly managed and unregulated grazing system, weak management interventions on pastureland development, increasing population pressure, landslides, have contributed to the depletion of the rangeland (GoN 2012). Likewise, timber-centric forest management has overlooked the management of grasses and fodder in high altitude areas. Similarly, the changing rainfall/snowfall pattern has directly affected the productivity of the pastureland.

\section{Hardship and Changing Social Values}

Herding in the high altitude region is increasingly turning into a less attractive occupation, from both social and economic points of view. This is mainly due to the fact that herders have to endure the hardship of high altitude life throughout the year. The newly emerging market trends, increased awareness of high altitude people about education and increasing employment options outside the area have resulted in decline in the interest towards following traditional occupation 
(Banjade and Paudel 2008). The present day notion has established herding as a dirty, labor intensive, wild and gauche, and is considered as illiterate people's job and therefore, has a low social reputation. The interest to continue this traditional occupation is very low among the young generation people who now work in and around city centers, are going abroad for jobs or want to continue their higher education in nearby cities. On the other hand, unpredictable climate has made the life of herders difficult; they have to face heavy rainfall and snowfall with strong wind, which usually destroy their huts.

\section{Increasing Conflict with Modern Formal Forestry Institutions}

The conflict in access to and control over resources between herders and $\mathrm{CF}$ in high altitude has been getting intense in recent years. The introduction of CF program did not adequately recognise the rights of the herders (Baral 2000). In many places, traditionally, herders had exclusive customary rights over resources. However, grazing was discouraged or prohibited in most of the community forests in Nepal as it was promoted as conservation centric management model; so the transhumance herding practices received little or no legal recognition while instituting $\mathrm{CF}$ in the area (Banjade and Paudel 2008). Similarly, the overlapping claims over the resources between herders and CFs are the crux of the conflict.

A number of other factors contributed in escalating conflict. Firstly, felling trees to make poles for making sheds and fences for herds, fuel wood for cooking and keeping their huts warm, (it occurs particularly during winter months when herders came down to the community forests for grazing) and collection of nontimber forest products (NTFPs) have fueled the conflict as other members of the CFUG would consider that as destructive or 'unfair' use by few herders. Secondly, the inadequate attention of CFUG on forest management activities as a result of CFUG's poor internal governance has also contributed to conflict. Thirdly, the climate change - induced vegetation change has resulted in increased conflicts. For instance, the grass species preferred by Chauri have decreased and now the Chauri take more area for grazing. In such situation, herders feed fodder through lopping trees which in turn has increased greater threat among the CFs towards forest sustainability ultimately increasing more restriction in grazing.

\section{CASE OF SUSPA- KSHAMAWATI COMMUNITY FOREST, DOLAKHA}

The case of Suspa-Kshamawati presented in this paper represents the third case study presented in contemporary literature focusing on this particular community forest. The first case was presented by Siktel (1995), 2nd by Baral (2000) and Baral (2015). The Suspa-Kshamawati CFUG is situated about $3 \mathrm{~km}$ north-west from Charikot, the district headquarter of Dolakha (Figure1). The CFUG was first registered in 1994 with the area of 150 hectares (ha) and later in 2003 it was expanded to 635 ha. According to the operational plan of Suspa-Kshamawati community forest in 2017 , the vegetation cover comprises of mixed natural forest with significant number of Pinus species and conifers such as Tsuga, Abies and Junipers and broadleaved species such as Quercus, Symplocox (Liso), Acer spp in the temperate regions and the higher elevation 
(sub-alpine areas), and Chilaune (Schima wallichii), Katus (Castanopsis indica) and rhododendron trees and non-timber forest products (NTFPs) like Lokta (Daphne bholua), Argeli (Edgeworthia gardeneri) in lower temperate and temperate region, and mushroom and wild vegetables. The forest encompasses three distinct altitudes or ecological regions (transition zone or lower temperate zone or winter pasture, temperate zone and subalpine zone (summer pasture) and lies in two aspects (south eastern and western with distinct vegetation).

The community is dependent on forests for construction materials, grazing, fodder, fuel wood and many agricultural implements and wooden household utensils. More than 60 per cent of the people here are Thami-the nomadic tribe, and one of the identified ethnic groups of Nepal. They are usually farmers and have day-to-day relations with the forest. Similarly, other groups include Sherpa, Shivakoti, Magar and Chhetris. Yak, goat and sheep herding is the traditional occupation of the Sherpa. Among the 302 households in the village, about 20 Sherpa households used to do Yak/Chauri herding. During summer, they used to take their Yaks towards the northern high altitude pasturelands. During winter, herders used to come down to the Suspa community forest, where they had to compete with the cattle of sedentary farmers and face restrictions from the CFUGs. In Suspa, there are four families involved in Yak herding, today whilst it used to be more than 20 families 30 years back. All households in the settlement are members of the CFUG. One member from each household takes part in the CFUG general assembly. A 15 member executive committee carries out every day management decisions which are endorsed by the general assembly.

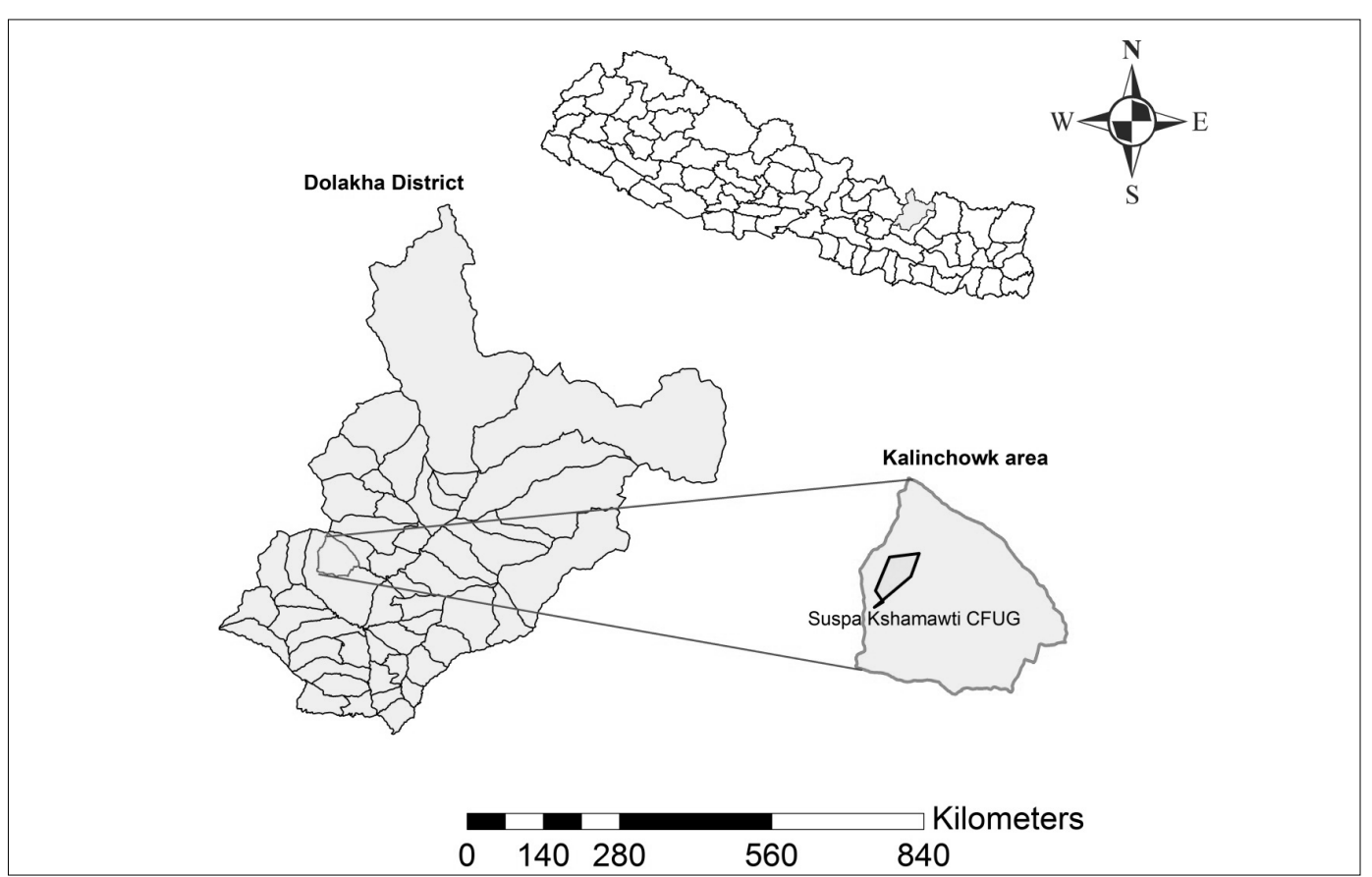

Figure 1: Map of the Research Site 
Suspa-Kshamawoti Kalinchowk region is one of the Yak herding regions in Dolakha district, which ranges in altitude from $2000 \mathrm{~m}$ (from Odare) up to $4000 \mathrm{~m}$ (in Kalinchowk) (Figure 2). The lower part of Suspa- Kshamawoti region is dominated by forest, settlement and agriculture ranging from $2000 \mathrm{~m}$ to $3000 \mathrm{~m}$. The forest is sub-tropical to temperate and sub-alpine with plenty of timber and NTFP species. Majority of the forests are managed by CFUGs. The Kalinchowk area, ranging from $3000-4000 \mathrm{~m}$, is mostly snowy area dominated by sub-alpine forest, grassland, bushy vegetation and very cold climate. There are also few households that have settled for religious and commercial purpose in the Kuri Bazzar of Kalinchowk area. The Kuri Bazzar is the market near Kalinchowk temple with around 40 houses (hotel, lodges and restaurants). It is connected with the road from Charikot and permanent electrification system. Ten years back, this area used to be a pastureland and one of the best herding points for Yak herders of this region.

Around five to seven different Yak herding points ${ }^{2}$ locally known as "kharka" can be found (Figure 2) in this region where the herders stay with their Yaks and family members in a small shed. They change the herding points based on the climatic variation and availability of grass. During the summer period, they move upwards to the Kuri-Kalinchowk area (summer pasture) which is the highest point for the herders and during winter they come down to the Odare area (winter pasture), which is the lowest point where they interact with the CFUGs. About 20 years ago, the lowest point used to be in 'Lathakhoriya' which is around 1600 meter in altitude, Due to increased settlement and frequent restriction on grazing from the CFUGs, the herders are obliged to move upward to the Odare region.

Before the establishment of community forest, the pasturelands were managed by the village councils comprising of 9-15 members nominated from within the community. The herders were assigned with certain pasture based on size of the herds and quality of the pasture. Certain tax was defined where the herders were required to pay on an annual basis. The herders used to have their permanent herding points at various altitudes which were used during the summer and winter seasons. Similarly, there used to be regular monitoring and reporting of the enforcement of rules by the council. Fair and equitable benefit sharing mechanism was followed irrespective of gender and wealth status (Acharya and Baral 2017).

\footnotetext{
${ }^{2}$ Herding points are the places where the yak herders take their yaks for grazing and they build a small house where they
} stay for 1-2 months each year. They stay in different herding points based on the climate and availability of grassland. 


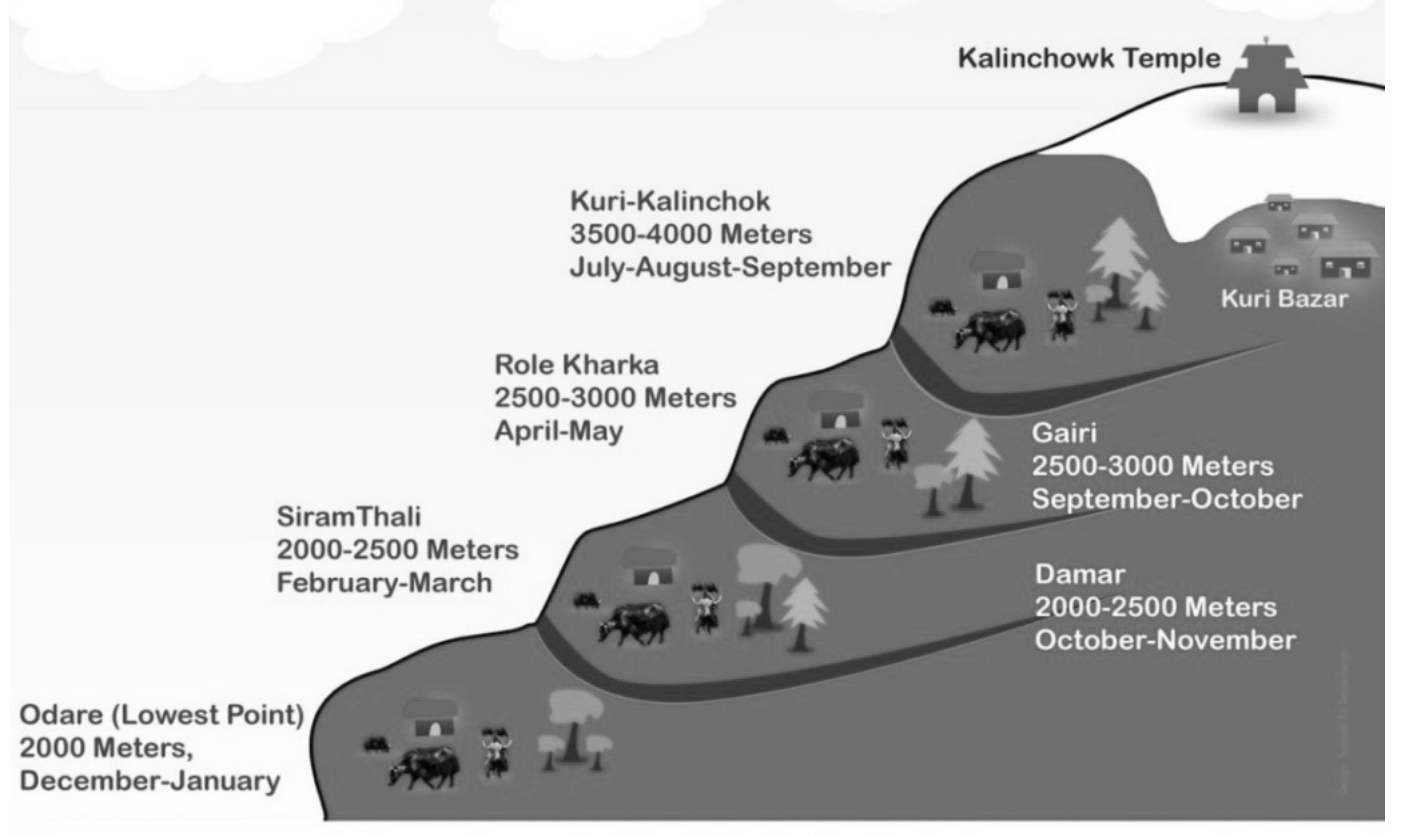

Suspa Kalinchowk Region

Figure 2: Herding points at Suspa-Kalinchowk Region

\section{KEY ISSUES AROUND HERDING IN SUSPA- KALINCHOWK REGION}

The transhumance herding practices is declining in Suspa Kshamawati Kalinchowk region. There are three major explanations around the decreasing herding practices as presented in the section above. First, both the quality and quantity of pastureland have declined over the past few decades. Second, the hardship, changing social values and emerging market trends and awareness of high altitude people about education and increasing option for employment outside the area contributed to leaving the occupation. Finally, the increasing conflict of herders with community forests in terms of their access to the pasturelands since some of these lands are managed as community forests is another reason.

\section{Declining Availability and Access to Quality Pasture Land}

Thirty years ago, Suspa-Kalinchowk region was one of the popular herding sites in Dolakha district with ample pastureland, fodder and grasses. Yak herding was the dominant occupation in this region particularly among the Sherpas. Their major livelihood income depended on the sale of Yak milk and ghee in Charikot Bazzar, the main market center and district headquarter. Now, herders have experienced noticeable decline in the quality and quantity of grass in the forests and grasslands. They used to spend more than three months in one herding point but now it's difficult to graze Yaks even for a period of two months. The pasture areas have been shrinking and converted to small market like the Kuri Bazzar. Almost 80 per cent of the pasture land has 
been occupied by markets and buildings. Grass and fodder which were easily available before are hard to find now. Similarly, areas where herding was carried out freely now have controlled access due to establishment of community forests.

Changing climatic condition, poor management of pasture land, and shrinking and encroachment of pasture for markets and other infrastructure development has contributed to declining quality of pasture land. Similarly, change in the rainfall timing, unpredictable snowfall and decrease in the amount of snowfall has contributed to decline in grass. There is no attention of the government on high altitude pasture management, where most of the areas are left barren and some of them have been encroached for infrastructure development. Most of the herders agree that the highland pastures and forests have almost no management attention. Likewise, unregulated and haphazard grazing and almost non-existent forest management ignoring sustainable forest management framework, rent seeking motive and harvesting good trees without giving due attention to the management of forests in a complex ecology without recognising the century-old indigenous system has led to declining productivity. Also, timber-centric forest management has overlooked the management of grasses and fodder in the high altitude areas. Subsequently, there is a significant decline in the number of herders in the last 20 years. More than 80 per cent of the herders have left this profession (Figure 3).

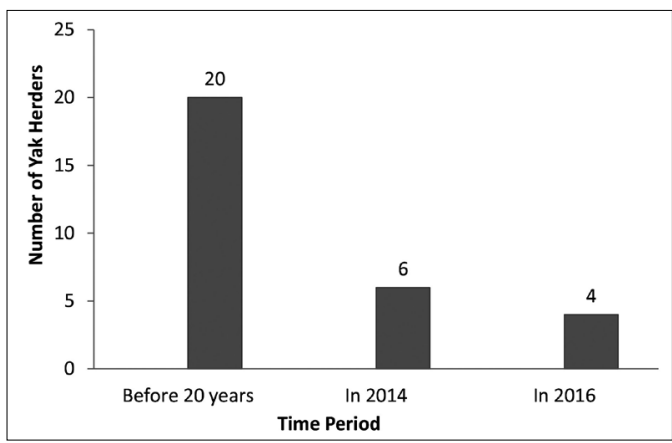

Figure 3: Status of Yak herders in SuspaKalinchowk Region

Doma Sherpa, one of the herders in the region shared;

...it is very difficult for us to predict the snowfall and rainfall these days. This year, there was a very strong storm and rain in December. I have not experienced such strong storm before and it destroyed our shed. There was also landslide because of heary and erratic rainfall. The amount of rain and snow fall is decreasing and has direct impact on regeneration of grasses and its availability. Now we have to move to other areas for Yak grazing in search of grass. There is also a change in the availability of different species of fodder and grasses... now the Khasru, Silungo, Liso species are very difficult to find in the forest.

\section{Hardship and Changing Social Values}

The lifestyle of herders in Suspa has been changing with the evolving socioeconomic context. Most of the herders have left the herding profession and 
moved to nearby towns and cities for jobs, business or to send their children abroad for jobs. Particularly, the Sherpa's who were once the main herders in the region are not much interested to continue this profession. The old generations of herders who used to endure their whole life in herding are not able to continue it and young generations of people are unwilling to continue herding as a profession. Due to the changing socio-economic context like decreasing social acceptance of this occupation, influence of the market, weak interest of their children to continue the profession and alternative opportunities outside herding, they have gradually accepted that herding is not an attractive occupation.

The young generations of people have no interest in living in the wild as they have to face natural calamities including storm, heavy rainfall, hailstones, in addition to attack by wildlife. They also have to be away from colourful social life that has been adopted by the city dwellers in recent years. Similarly the herders also want their children to stay in the city area (Charikot, Kathmandu) for education, and to have a decent job. Many of them go abroad for education and wage labor. Similarly, the changing climate has increased adversities for the herders. Unpredictable rain and heavy snowfall, strong storms, and hailstones have made their lives difficult. Ngwa Sherpa, a herder in Dolakha shared;

There is a declining interest of the young people in this profession with increasing attraction to go abroad for jobs. Similarly, the changing lifestyle of young people does not match with the herding profession which is very labour intensive and they call it a "dirty profession".

\section{Conflict between Herders and Community Forest User Group}

The conflict between the herders and the CFUG is another key issue that has posed challenge to herding in the Suspa region. Primarily, weak tenure recognition between the customary practices of herding and the formal process of $\mathrm{CF}$ has triggered conflict as the former needs to compete with the latter for grazing in and around community forests during the winter seasons. The herders have lost their customary rights in terms of their access to forests and pasturelands due to the establishment of new institutions like the CFUGs thereby giving rise to conflict related to resource use. The provisions in the CFUG operational plans impose restrictions on grazing within the community forest area. However, herders have to come down to the forests to graze their Yaks during winter for around two to three months where they have to interact with the CFUGs. Similarly, they have to construct sheds within the forest area and use fuel wood for heating and cooking. Often they are warned by the CFUG leaders not to build sheds and graze Yaks freely.

On the other hand, the community forest users who are practicing sedentary agriculture put pressure to their leaders not to allow open grazing to herding. Usually, users claim that the herders are earning significantly higher income from herding using the common resources and that they use the resources haphazardly. Similarly, compared to the CFUG members who usually have few livestock, one herder owns more than 20 Yaks, which is significant in terms of number. This has created pressure over the CFUGs to restrict open grazing. 
Kul Bahadur Thami, a farmer and a user of Suspa CFUG lamented;

We, the users, have ferw livestock; 2, 3 cows and buffaloes per household. However one yak herder has more than 20 yaks. If herders are let open for grazing, we will also increase the number of our livestock and graze openly!

On the other hand, climate change induced vegetation change has aggravated conflict between community forest and the herders' group. The grass species preferred by the Yaks/Chauris like Khasru, Silungo,
Liso, have significantly decreased and some have already disappeared in the region. As a result, Yaks now take longer period and cover wider area for grazing. Similarly, herders are feeding fodder through lopping trees. Thus, because of these activities, community forest users feel a greater threat towards the sustainability of forests, thus aggravating conflict. Ultimately, herders are the ones to lose, as herding has been an easy way to utilise natural resources of high altitude region in the form of extended pasture land. The increasing contestations and other issues has created problem for herding to function smoothly.

\section{A HERDER'S STORY}

"The lifestyle of people has changed. The young generation has low interest towards this profession. They are moving to cities for higher education and abroad for jobs. Similarly the CFUGs' policies to ban grazing have discouraged the herders and they are declining. There used to be 20 herds in one CFUG 15 years back but now, we hardly have 4 herds. There is a lot of misunderstanding between CFUGs and yak herders. CFUGs always tell us that yaks graze heavily and destroy the grasslands. They even blame us for haphazard cutting of trees for fuel wood and illegal collection and sale of (NTFP) but they don't blame other users (livestock herders) who are also forest dependent. Yaks feed only on the available grasses and can sustain for days with what they have. Due to the lack of awareness and shortage of grasses, some herders nowadays completely harvest fodder trees." These are the grudges that Ngwa Sherpa, a Yak herder in Dolakha district expressed during an interaction. It has always been difficult for $\mathrm{Ngwa}$ and other Yak herders to maintain this occupation. Where once considered as an easy and interesting work is now no more attractive and is an area of contestation with other CFUGs.

Similarly, he shared, "The CFUGs always decide by themselves, herders' voices are not heard in the general assembly and in the decision making process. We are not even informed about the meeting. Currently, we are paying heavy taxes yearly and still we are not allowed to graze." The present Chairperson of the CF is a Sherpa, so this has relatively made it easier for the herders to graze their Yaks in the CF. However, it is assumed that there might be problem after his replacement.

The conflict has existed for the past 30-40 years. However, in the present context, the number of Yaks is declining. The forest regeneration is slow and CFUGs are restricting grazing. Similarly, grazing land is decreasing and sudden changes in climate in the region have added to difficulty in herding these days. With sombreness in his face, Ngwa expressed, "If the same trend continues, Yak herding occupation will be extinct in the near future. The existing problem will be solved only if the conflicting parties i.e. Yak herders, the CFUGs, and related stakeholders carry out dialogue and come up with a win-win situation". 


\section{DISCUSSION}

High altitude pastoralism is a unique model of livelihoods system that is characterised by seasonal movement of herders with their cattle and make their living through income from cattle-based products complemented by collection and trade of NTFPs. While the herding has been a relatively secured livelihoods strategy of many people living in the high mountains until recently, the profession has been met with unprecedented challenges and is at the verge of collapse unless government and other relevant actors offer appropriate policy and programmatic support. It is well documented that the livelihoods of the transhumance pastoralists have been threatened and several socio-cultural, economic and ecological consequences have also been experienced (Banjade and Paudel 2008; Acharya and Baral 2017).

The problem is primarily rooted in the ignorance of the state as evidenced by the lack of recognition by regulatory frameworks of the historically held indigenous knowledge and long practiced resource conservation, use and management. Furthermore, the provisions in Forest Act and Regulations particularly related to $\mathrm{CF}$, have arguably limited the access of pastoralists to the resources, and thereby, inducing conflict among stakeholders. Though the actual implication on the ground is yet to be seen, the case study area now lies within the newly declared Gaurishankar Conservation Area. This means that the herders have to follow the conservation area rules which are normally stricter in terms of resource access and management (Acharya and Baral 2017).
In addition to the regulatory constraints, skewed number and size of the herds, which is also argued to be at the risk of extinction, is largely attributed to the considerable changes in ecological, socioeconomic and climatic conditions. Forest degradation and loss of biodiversity is in an increasing trend in the high altitude areas. The site specific studies (Hinrichsen et al. 1983; Jackson et al. 1998; Gerrard et al. 2016) have reported excessive deforestation and forest degradation. Similarly, the shrinking of grazing land for mobile pastoralists, newly emerging market trends, increased awareness of high altitude people about education and increasing options for employment outside the area have posed threats to this traditional occupation (Banjade and Paudel 2008). The infrastructure development in high altitude areas has induced fragmentation of forests and habitat. Construction of roads, hydropower, temples, and market among others, has not adequately considered the ecological fragility and its significance in high altitude area.

Similarly, temperature trends suggest that warming is more pronounced in the northern high altitude areas than in the lower elevations of Nepal (GoN 2010). The climate change effects on herding practice, especially on availability and quality of pasture, seasonal movement of yaks, grazing behavior, feeding system and overall herding pattern were visible in the case of Suspa. These changes have increasingly posed challenges to the herders and many have given up their occupation. The study by Dhakal et al. (2005) in three mid-hill districts (Dolakha, Kavre and Nuwakot) and by Pandey and 
Chhetri (2005) in Upper Mustang found that the grass availability in the pasture has been decreasing in recent years. Similarly, Herders are facing problem of shrinking grazing land, encroachment of grazing land by newly bourgeoning towns and other infrastructures. This shows that the rangeland is degrading day by day and little attention has been paid on its condition and sustainable management. There is sharp loss of native species in the pasture, and no plantation, or any propagation intervention can be seen. Consequently, there is a gradual degradation in vegetation (Parajuli et al. 2013). At the same time, deforestation, forest fires, soil erosion and landslide are becoming common. Dong (2011) reported that the herders may be disproportionately more vulnerable due to climate change and the situation could be even more severe when the flexibility of herders is restricted ( $\mathrm{Fu}$ et al. 2012).

Conflict between the mobile herders and CF institutions surfaced largely because the latter started imposing restrictions to the traditional herders on use of forest territories for pasture and other uses. The conflict has surfaced partly due to the misunderstanding between the herders and CFUGs. The CFUG leaders believe that herders make relatively higher income by utilising the community forest resources while overlooking the negative impacts of grazing on the forest. In contrast, herders claim that the CFUGs have unfairly imposed restrictions over their access to grazing land. Similarly as herders have to migrate seasonally from one place to other, they cannot participate in regular CFUGs' decision making process and consequently, are less aware of rules on governing the forest resources, including grazing. Even if herders participate in the village assemblies, their voices are ignored or are not addressed adequately. Thus, the existing nature of conflict between the mobile herders and sedentary peasants is also manifested from the perception that practice of the herders in grazing, making temporary structures, using fuelwood, and extracting NTFPs is 'unsustainable' as they 'over exploit' the resources. The perception also is advanced around the disproportionate benefits that would be syphoned by the few herders from the forest that have equal rights with other members.

As conflict accounts as one of the most important factors for sustaining and thriving transhumance pastoralism in the study area and other parts of Nepal, resolving and transforming conflict merits more attention. Adaptive learning approaches of conflict resolution applied in community forestry settings could be worth pursuing in these contexts as well. For that, as discussed in the above section, an adaptive learning based on bringing all parties together and facilitating deliberative processes including developing mechanism for two-way communication and information flow between the herders and CF members appeared to have been helpful in exploring negotiated solutions that reduced such conflicts. The Suspa case of facilitating action learning approach for conflict resolution was successful although the intervention was very brief from the external facilitators.

Changing socio-economic dynamics that often devalues herding and drives youths away from herding emerged as another important factor shaping the future of herding in the region. As the youths are increasingly connected to the outside 
world, many of them have begun to see their future away from the mountain. Parents have seen value in enrolling their children in modern schools, preferably private ones. The young graduates are interested to do jobs in cities or even abroad. As observed by Pandey and Chhetri (2005) in the Upper Mustang, the herder numbers has been decreasing and they are moving to nearby cities. They found that there were more than 30 nomad families in the Upper Mustang some 25-30 years back, while at the present, there are only nine of such families. The availability of alternative occupation besides herding and exposure of people to outside world has undermined herding in the mountain. Similarly, there is poor social recognition and prestige of the profession. On the other hand, the herders don't want their children to endure their whole life in herding and stay away from the developing world. They don't see a lucrative career of their children in herding.

\section{CONCLUSIONS AND POLICY IMPLICATIONS}

The above exploration reflects that the high altitude herding has both socioeconomic and ecological significance. There are diverse challenges around high altitude herding including growing conflicts between the herders and CFUGs, the socio-economic changes, climate change impacts and government policy failure. Consequently, in a substantial decrease in the number of herders has been observed in the recent years, and it demands different sets of strategies in a coherent framework of intervention.

The pastoralist-CF members' conflict, the hardship of herding and changing social values against it, degrading pasture quality, effects of changing climate and unclear policy and regulatory frameworks were identified as the key factors contributing to the mounting challenges to mountain pastoralism. These factors collectively, have contributed to high costs of production, reduced farm productivity, and demotivating herders. The paper also brought the case of Kalinchowk region with the details of everyday issues and concerns that need urgent action.

The findings entails that there needs a major rethinking in the current policy and institutional form of CF as it favours the sedentary community. Accordingly, the legal and regulatory provisions on users' identification, CFUG structure, its operational plans and institutional processesshould be revised to accommodate the herders and their resource use patterns. Similarly, institutionalisation of herders' issues through collective measures could help develop the herding size and maintains grazing cycle as per the resource availability and carrying capacity of pasture. For this the District Forest Office (DFO) and other concerned institutions could facilitate the process. Most importantly there is information/ knowledge gap in the DFO staff regarding the way these customary practices function. The government programs and policy interventions for development and management of high altitude herding seem inadequate.

Most of the policies and programmes have largely failed to recognise and address the unique socio-cultural, economic and ecological features of high mountain region. The unclear arrangement of rights and lack of recognition of customary use rights of the herders in current form of forest management modalities appears to be one of the key problems. Similarly, 
the understanding of ecological changes among the stakeholders is also poor. For instance, the understanding of the grazing cycle, grazing pattern, the need and use of forest resources for herder's, new tools and techniques for pasture land management among the CFUGs is inadequate and needs to be developed and experimented. Thus the high altitude herding has been facing multiple challenges which are largely produced by poor governance and weak and unclear policy arrangement. Moreover, climate change effect has aggravated the challenges ultimately resulting to declining interest and number of herders.

It is clear that the climate change has caused multiple effects on herding system. Sensitisation and facilitation on climate change adaptation measures and coping strategies to the herders should be a priority action. To encourage and attract youths towards this profession, specific incentive considering socio-economic drivers should be developed. In order to resolve the enduring conflict between the herders and sedentary peasants, deliberation that embraces social learning approaches among various actors could be an appropriate strategy. While, mitigating herders-CF conflicts does not provide a sole answer to mountain pastoralism, it would substantially ease their everyday life and may encourage them to retain on this culturally embedded practice. This is the key to sustain local economy in the region. Equally important is the knowledge gap on high altitude pastoralism. Interdisciplinary studies, socio-economic dynamics, climate change, vegetation changes, policy impacts and future prospects of pastoralism can help design and implement more effective policies and programmes that help develop a more resilient mountain economy in which pastoralism become a good part.

\section{ACKNOWLEDGEMENTS}

This paper is based on research conducted under the Community-based Adaptive Learning in management of Conflicts and Natural Resources in Bangladesh and Nepal (CALCNR) project. The project was supported by the Netherlands Organisation for Scientific Research (NWO) grant no. W 07.68.2012.424 with funding from the United Kingdom Department for International Development (DFID). We are grateful to our colleagues and the leaders and members of all of the participating CFUGs, FECOFUN and anonymous reviewers.

\section{REFERENCES}

Acharya, D. 2003. Natural Resource Management in High Altitude Areas in Nepal: A Review and Synthesis of Information. Livelihoods and Forestry Programme (LFP), Kathmandu, Nepal.

Acharya, D. and Baral, N.R. 2017. Neglected High Altitude Rangelands of Nepal: Need for Reform. Journal of Forest and Livelihoods, 15(1): 103-119.

Banjade, M.R. and Paudel, N.S. 2008. Mobile Pastoralism in Crisis: Challenges, Conflicts and Status of Pasture Tenure in Nepal Mountains. Journal of Forest and Livelihoods, 7(1): 49-57.

Baral, N.R., Acharya, D.P., and Rana, C.J. 2012. Study on Drivers of Deforestation and Degradation of Forests in High Mountain Regions of Nepal. REDD-Forestry and Climate Change Cell, Ministry of Forests and Soil Conservation, Government of Nepal, Kathmandu, Nepal.

Baral, N.R. 2001. Study of Exclusion and Equity in the High Altitude Region as an Implication of Community Forestry: Experiences from Sindhupalchok and Dolkha

Baral, N.R. 2015. Documentation and Assessing Customary Practices of Managing Forest Resources at Local Level. REDD Implementation Centre, Ministry of Forests and Soil Conservation, Government of Nepal, Kathmandu, Nepal. 
Barsila, S.R. 2008. Livestock and Rangeland in Selective High Altitude Districts of Nepal: A Review. Initiative for Social Transformation Nepal, Kathmandu, Nepal.

Bauer, J.J. 1989. Grassland Ecology of the Himalayan Region: Survey Manual. Rome: Food and Agriculture Organization.

Bauer, K.K. 2004. High Frontiers: Dolpo and the Changing World of Himalayan Pastoralists. New York: Columbia University Press.

Brower, B. 1990. Range Conservation and Sherpa Livestock Management in Khumbu, Nepal. Mountain Research and Development, 10(1): 3442.

DFRS. 2015. State of Nepal's Forests. Department of Forest Research and Survey (DFRS), Government of Nepal, Kathmandu, Nepal.

Dhakal, B., Bigsby, H. and Cullen, R. 2005. Impacts of Community Forestry Development on Livestocks Based Livelihood In Nepal. Journal of Forest and Livelibood, 4 (2).

Dong, S., Wen, L., Liu, S., Zhang, X., Lassoie, J.P., Yi, S., Li, X., Li, J. and Li, Y. 2011. Vulnerability of Worldwide Pastoralism to Global Changes and Interdisciplinary Strategies for Sustainable Pastoralism. Ecology and Society, 16: 2-10.

Fu, Y., Grumbine, R., Wilkes, A., Wang, Y., Xu, J.C. and Yang, Y.P. 2012. Climate Change Adaptation among Tibetan Pastoralists: Challenges in Enhancing Local Adaptation through Policy Support. Environmental Management, 50(4): 607-621.

Gerrard, R., Kohler, T., Price, F., Byers, A.C., Sherpa, A.R. and Maharjan, G.R. 2016. Land Use and Land Cover Change in Sagarmatha National Park: A World Heritage Site in the Himalayan of Eastern Nepal. Mountain Research and Development, 36(3): 299-310.

Ghimire, S.K. and Parajuli, D.B. 2001. Indigenous Knowledge and Practice of Pasture Management among the Pugmo People of Shey Phoksundo National Park, Dolpo. The Wildlife Magazine, 3(1): 7-14.

GoN. 2010. National Adaptation Program of Action, 2010. Ministry of Environment, Science and Technology, Government of Nepal, Kathmandu, Nepal.

GoN. 2012. Rangeland Policy 2012. Government of Nepal, Kathmandu, Nepal.
GoN. 2014. Annual Report 2013/14. District Livestock Development Office, Government of Nepal, Dolakha, Nepal.

GoN/MoFSC. 2014. Nepal Biodiversity Strategy and Action Plan 2014-2020. Government of Nepal/ Ministry of Forests and Soil Conservation, Kathmandu, Nepal.

GoN/MoLD. 2017. Livestock Statisticts of Nepal. Government of Nepal/Ministry of Livestock Development, Kathmandu, Nepal.

Hinrichsen, D., Lucas, P., Coburn, B. and Upreti, B.N. 1983. Saving Sagarmatha. Ambio, 12(3-4): 203-205.

Jackson, W.J., Tamrakar, R., Hunt, S. and Shepherd, K.R. 1998. A Comparative Study of Land Use in the Two Middle Hills Districts of Nepal. Mountain Research and Development, 18(3): 193-212.

Joshi, D.D. 1994. Yak Production in Nepal. Proceedings of the First International Congress On Yak. Journal of Gansu Agricultural University (Special Issue, June 1994). Pp. 105-112. [Reprinted in Asian Livestock (Fao Bangkok), 1994, Xix (10), 132136.

Mcveigh. C. 2004. Himalayan Herding is Alive and Well: The Economics of Pastoralism in the Langtang Valley. Nomadic Peoples, 8(2): 107124.

Ning W., Rawat, S.G. and Sharma, E. 2013. High-Altitude Ecosystem Interfaces in the Hindu Kush Himalayan Region. International Center for Integrated Mountain Development, Kathmandu, Nepal.

Pandey M.R. and Chhetri, M. 2005. Nomads and Pastoralism: Linkage with Biodiversity Conservation in Upper Mustang, Nepal. Our Nature 3:42-49.

Parajuli, D.P., Paudel, L.N. and Gyawali, R.R. 2013. Changes in Pastoral Production Systems in High-Altitude Village-Rangeland Interfaces in Nepal. Special Issue, 30, International Center for Integrated Mountain Development, Kathmandu, Nepal.

Shrestha, B.S., Joshi, B.R. and Joshi, H.D. 2006. Migratory Small Ruminants: Their Potential and Economic Contribution in the High Hills and Mountains of Nepal. In: Proceedings of the 6th National Workshop on Livestock and Fisheries, 1-2 July 2004, Nepal Agricultural Research Council, Lalitpur, Nepal.

Siktel, K.P. 1995. Fug Conflicts in Dolkha and Ramechap. Banko Jankari, 5(3): 116-119. 